\title{
Intralenticular copper foreign body
}

\author{
Mariya Bashir Doctor, ${ }^{1}$ Deepika C Parameswarappa (1) ,' Pravin Krishna Vaddavalli, ${ }^{3}$ \\ Padmaja Kumari Rani (D) ${ }^{1}$
}

${ }^{1}$ Cataract and Refractive Services, LV Prasad Eye Institute, Hyderabad, Telangana, India ${ }^{2}$ Vitreo-retina, LV Prasad Eye Institute, Hyderabad, Telangana, India

${ }^{3}$ Cornea Service, LV Prasad Eye Institute, Hyderabad, Telangana, India

\section{Correspondence to}

Dr Padmaja Kumari Rani, rpk111@gmail.com

Accepted 30 November 2020

\section{DESCRIPTION}

A 34-year-old man, an electrician by occupation, presented with blurring of vision and pain in his right eye for the past 5 days. He had consulted elsewhere and was diagnosed with an intra-lenticular foreign body and was prescribed topical antibiotics, anti-inflammatory and antiglaucoma drops. The patient was not aware of any recent trauma; on examination, the patient had a best-corrected distance visual acuity (BDVA) of 20/20 in the right eye and 20/20 in the left eye. On slit-lamp biomicroscopy, the right eye had mild conjunctival congestion and a nebular grade corneal scar located in the paracentral cornea at about 6 o' clock, with a small fragment of copper wire embedded in the lens matter from 6o c to 9o clock, and an intact posterior capsule. The anterior chamber showed $1+$ cells and intraocular pressure was $18 \mathrm{~mm} \mathrm{Hg}$ (figure 1). Posterior segment examination was unremarkable without any evidence of a foreign body. The computed tomography scanconfirmed the location of the isolated intralenticular foreign body. The anterior and posterior segment examination of the left eye was unremarkable. The patient underwent foreign body removal with lens aspiration and intraocular lens implantation in the right eye, given the risk of anterior uveitis with raised intraocular pressures. At the 1-month postoperative visit, his BDVA was 20/20, with no conjunctival congestion

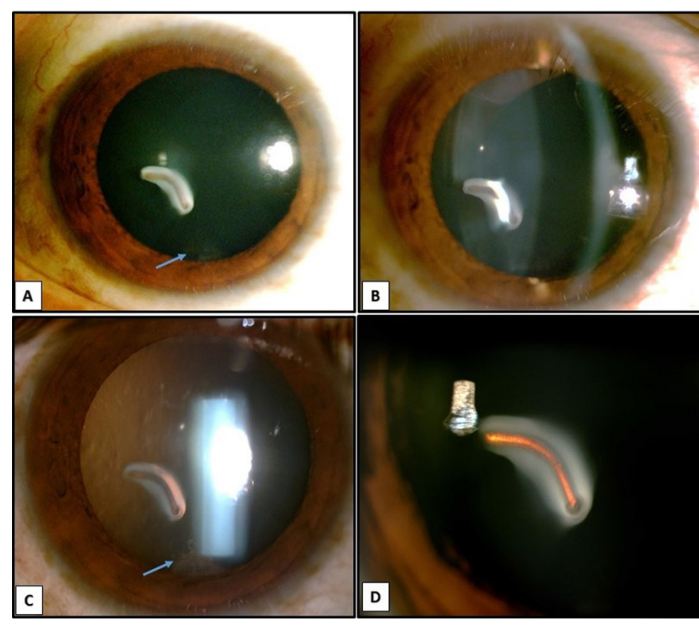

Figure 1 (A) Diffuse slit lamp image showing nebular grade corneal scar at 6 o' clock (blue arrow), copper coloured foreign body within the lens, surrounded by a localised lenticular opacity. $(B, C)$ The intralenticular foreign body identified via optical section and retro illumination techniques (blue arrow shows the corneal scarring). (D) A magnified view of the intralenticular foreign body. and a quite anterior chamber without any cellular reaction.

Intralenticular metallic foreign bodies usually cause localised opacities or lead to the development of total cataracts depending on the size of the foreign body and its chemical contents. Ocular toxic effects are usually not encountered since the lens capsule acts as a barrier. ${ }^{1}$ In our case, the foreign body was a fragment of coated copper wire present within the substance of the crystalline lens. Additionally, copper foreign bodies are known to induce a fibrous capsulation around them, which reduces the potential toxicity of copper to the other ocular structures as seen in our case. ${ }^{23}$ However, whenever encapsulation does not occur, copper can lead to devastating ocular inflammation. Indications for surgery in an encapsulated copper intralenticular foreign bodies are the formation of a cataract, anterior uveitis, glaucoma and lens subluxation. In chronic cases, chalcosis can lead to characteristic findings such as sunflower cataract, Kayser-Fleischer ring, focal pigmentary changes in the fundus, chorioretinal atrophy and endophthalmitis. ${ }^{4-6}$ Hence early surgical intervention, as in our case, provides the best opportunity to tackle the condition's acute complications as well as preventing long-term damage while maintaining a good visual outcome. ${ }^{78}$

\section{Learning points}

An intralenticular encapsulated copper foreign body may lead to a localised cataract and mechanical damage to the surrounding ocular structures.

- Early surgical intervention for the intralenticular encapsulated copper foreign body is indicated in the presence of cataract, anterior uveitis, glaucoma and lens subluxation.

- Timely surgical intervention is recommended to prevent long-term damage with good visual outcome.

Twitter Pravin Krishna Vaddavalli @pravinkrishna

Contributors Data collection, manuscript writing and review of literature: MBD and DCP. Manuscript review: PKV and PKR. Operating surgeon: PKV.

Funding The authors have not declared a specific grant for this research from any funding agency in the public, commercial or not-for-profit sectors.

Competing interests None declared.

Patient consent for publication Obtained.

Provenance and peer review Not commissioned; externally peer reviewed. 


\section{ORCID iDs}

Deepika C Parameswarappa http://orcid.org/0000-0002-5302-1070

Padmaja Kumari Rani http://orcid.org/0000-0001-7069-8238

\section{REFERENCES}

1 Lee W, Park SY, Park TK, et al. Mature cataract and lens-induced glaucoma associated with an asymptomatic intralenticular foreign body. J Cataract Refract Surg 2007;33:550-2.

2 Cordes FC, Harrington DO. Bilateral absorption of intraocular copper with chalcosis in one eye. Am J Ophthalmol 1935;18:348-52.
3 Mishler JE, HARLEY RD. Copper within the eye 30 years simulating tumor; report of a case. Am J Ophthalmol 1952;35:687-90.

4 Agarwal R, Goel Y, Anand K. Sunflower cataract in chalcosis bulbi. Indian J Ophthalmol 2019;67:137.

5 Ugarte M, Nicol DA, Jones NP, et al. Chronic intraocular copper foreign body and Candida: a unique combination. Ocul Immunol Inflamm 2009;17:356-60.

6 Rao NA, Tso MO, Rosenthal AR. Chalcosis in the human eye. A clinicopathologic study. Arch Ophthalmol 1976:94:1379-84.

7 Beckerman BL. Intraocular foreign body extraction in early chalcosis. Arch Ophthalmol 1972;87:444-6.

8 Lin Y-C, Kuo C-L, Chen Y-M. Intralenticular foreign body: a case report and literature review. Taiwan J Ophthalmol 2019;9:53.

Copyright 2020 BMJ Publishing Group. All rights reserved. For permission to reuse any of this content visit

https://www.bmi.com/company/products-services/rights-and-licensing/permissions/

BMJ Case Report Fellows may re-use this article for personal use and teaching without any further permission.

Become a Fellow of BMJ Case Reports today and you can:

- Submit as many cases as you like

Enjoy fast sympathetic peer review and rapid publication of accepted articles

- Access all the published articles

Re-use any of the published material for personal use and teaching without further permission

\section{Customer Service}

If you have any further queries about your subscription, please contact our customer services team on +44 (0) 2071111105 or via email at support@bmj.com.

Visit casereports.bmj.com for more articles like this and to become a Fellow 